\section{OPEN ACCESS}

Approved by:

Gerald Matthews,

University of Central Florida,

United States

${ }^{*}$ Correspondence:

Frontiers Editorial Office

editorial.office@frontiersin.org

Specialty section

This article was submitted to

Personality and Social Psychology,

a section of the journal

Frontiers in Psychology

Received: 16 November 2020

Accepted: 16 November 2020

Published: 17 December 2020

Citation:

Frontiers Editorial Office (2020)

Retraction: When Words Hurt: Affective Word Use in Daily News Coverage Impacts Mental Health.

Front. Psychol. 11:630044. doi: 10.3389/fpsyg.2020.630044

\title{
Retraction: When Words Hurt: Affective Word Use in Daily News Coverage Impacts Mental Health
}

Frontiers Editorial Office*

\section{A Retraction of the Original Research Article}

When Words Hurt: Affective Word Use in Daily News Coverage Impacts Mental Health by Wormwood, J. B., Devlin, M., Lin, Y.-R., Barrett, L. F., and Quigley, K. S. (2018). Front. Psychol. 9:1333. doi: 10.3389/fpsyg.2018.01333

The journal retracts the 2 August 2018 article cited above.

This paper reports a study that involved data collected at three time points. The authors recently discovered a clerical error in how the data were merged across time points. Specifically, data collected during the final longitudinal time point (wave 3 ) were incorrectly assigned to the wrong participants when merging data files. The authors have corrected this error and re-conducted the analyses and the pattern of findings reported in the paper are no longer supported by the analyses.

The authors concur with the retraction and sincerely regret any inconvenience this may have caused to the reviewers, editors, and readers of Frontiers in Psychology.

Copyright $\odot 2020$ Frontiers Editorial Office. This is an open-access article distributed under the terms of the Creative Commons Attribution License (CC BY). The use, distribution or reproduction in other forums is permitted, provided the original author(s) and the copyright owner(s) are credited and that the original publication in this journal is cited, in accordance with accepted academic practice. No use, distribution or reproduction is permitted which does not comply with these terms. 